\title{
Heavy metal analysis in the soils of in and around Robe town, Bale zone, South Eastern, Ethiopia
}

\section{Maneyahilishal Tefera a, Ftsum Gebreyohannes ${ }^{b}$, Mekala Saraswathi ${ }^{b}$,*}

a Department of Environmental Science, School of Natural and Computational Sciences, Maddawalabu University, Ethiopia

${ }^{b}$ Department of Chemistry, School of Natural and Computational Sciences, Maddawalabu University, Robe, Bale, Ethiopia

\section{Article Info}

Received : 25.11.2017

Accepted : 27.05 .2018

\begin{abstract}
The purpose of this study was to assess physicochemical parameter and heavy metal concentration of the soil in and around Robe town, Bale zone, Ethiopia. Seven soil samples (three from dump sites and four from farm lands) were collected and analyzed through different methods for analyzing the physicochemical parameters like, $\mathrm{pH}$ Sand/Silt/Clay Content, MC, OM. and the heavy metals including $\mathrm{Cr}, \mathrm{Cd}, \mathrm{Cu}, \mathrm{Fe}, \mathrm{Zn}$ and $\mathrm{Pb}$, were investigated using Flame atomic absorption spectrophotometer (FAAS). The analyzed result of all sites revealed that, high moisture content \% (14.83 \pm 2.57 to $19.96 \pm 0.72)$, pH slightly acidic except S2 which is slightly basic, (5.77 \pm 0.08 to $7.60 \pm 0.33$ ),high organic matter \% (13.83 \pm 0.49 to $16.60 \pm 0.90)$, sand \% (53.00 \pm 4.51 to $65.33 \pm 2.42$ ), silt \% $(19.33 \pm 1.03$ to $24.84 \pm 4.62)$, clay $\%(11.33 \pm 1.03$ to $19.50 \pm 2.50)$ sandy nature of soil were observed and the concentration of heavy metals such as: $\operatorname{Cr}(32.53 \pm 3.51$ to $41.81 \pm$ 1.06) ppm, $\mathrm{Cd}(0.57 \pm 0.21$ to $0.93 \pm 0.24) \mathrm{ppm}, \mathrm{Cu}(26.54 \pm 0.68$ to $37.44 \pm 2.72) \mathrm{ppm}, \mathrm{Zn}$ $(66.98 \pm 1.09$ to $170.48 \pm 1.51)$ ppm Fe (33483.55 \pm 1470.02 to $49012.18 \pm 2692.20)$ ppm and $\mathrm{Pb}(18.04 \pm 0.37$ to $20.77 \pm 0.46)$ ppm were obtained. The results showed that all of the assessed heavy metals below maximum permissible limit except Fe, which is above maximum permissible limit that recommended by Ewers, Based on the results obtained from the study the level of metals concentrations safe for agricultural activities. But different measures must be taken to minimize additional soil pollution.
\end{abstract}

Keywords: Dump site, farm land, physicochemical parameters, heavy metals, FAAS.

(C) 2018 Federation of Eurasian Soil Science Societies. All rights reserved

\section{Introduction}

Soil can be defined as unconsolidated minerals or organic material on the immediate earth's surface and it serves as a natural medium for plant growth and other activities (Brady and Weil, 2008). It is one of the important and valuable resources of the nature, which has complex functions beneficial to human and other living organism (Addis and Abebaw, 2014). It also acts as a filter, buffer storage, transformation system and thus protects the global ecosystem against the adverse effects of environmental pollutants (Sumithra et al., 2013). Environmental sustainability largely depends on the availability of soil ecosystem and any alterations as a result of either pollution or contamination that alters the ecosystems and agricultural activities (Hong et al., 2014). Fertile soil and a congenial climate for productivity are valuable assets for any nation. But, due to human activities, soil has become a receptor of many pollutants including pesticides, fertilizers, particulate matters, and heavy metals. Contamination of soils by different pollutants results serious environmental problem and it has significant influence on human health processes (Rahaman et al., 2015).

Heavy metals are metals and metalloids having atomic densities greater than $5 \mathrm{~g} / \mathrm{cm}^{3}$. Heavy metals include: copper, iron, mercury, zinc, arsenic, silver, lead, chromium etc. Since heavy metals are not biodegradable; they persist and accumulate over a long time in the soils and vegetation resulting to serious environmental pollution (Mtuazi et al., 2015). Due to natural existence of heavy metals are in soil; high concentrations of

\footnotetext{
${ }^{*}$ Corresponding author.
}

Department of Environmental Science, School of Natural and Computational Sciences, Maddawalabu University, Robe, Bale, Ethiopia 
these metals exhibit chronic effects as well as fatality (Olayinka et al., 2011). Various forms of heavy metals in the soil of greatest concern are the exchangeable and the soluble, because these, are the forms that are available to plants. All negative effects of heavy metals start from their absorption by plants, and to a lesser extent by ground water contamination through leaching. As metals are absorbed by plants, they introduced into the food chain (Dawaki et al., 2013).

In Ethiopia, day to day drastically increases the usage of chemical fertilizers instead of manures for crop productivity but because of chemical fertilizers the quality of the soil is reducing. Therefore, it is essential to analyze the physicochemical characteristics of soil. Results of physical and chemical tests provide the information about the ability of the soil to supply mineral nutrients. The soil condition is an important factor as it is an universal medium for plant growth, which supplies essential nutrients to the plants (Wodaje and Alemayehu, 2014). Soil physicochemical parameters like, soil pH, texture and organic matter contents are important with regards to the forms of the heavy metals and their bioavailability (Aydinalp and Cresse, 2009). On the other side, in developing countries the open dumping strategy is common due to the low budget for waste disposals and non-availability of trained manpower (Ali et al. 2014). The municipal solid waste has been found to contain an appreciable quantity of heavy metals, which may eventually end up in the soil and leach down the profile. This makes municipal solid waste one of the principal sources of heavy metals in the environment (Parameswari et al., 2015). Indiscriminate and unscientific dumping of municipal wastes is very common in many cities of Ethiopian. The present study is an attempt to evaluate and compare the potentially bioavailable concentrations of some principal heavy metals, particularly, $\mathrm{Fe}, \mathrm{Zn}, \mathrm{Cu}, \mathrm{Pb}, \mathrm{Cr}$ and Cd in some selective farm lands and dumpsites in and around the Robe town, Ethiopia..

\section{Material and Methods}

\section{Description of the Study Area}

The study was carried out at around Robe town, which is located North-Eastern of Ethiopia, with a latitude and longitude of $7^{\circ} 7^{\prime} \mathrm{N} 40^{\circ} 0^{\prime} \mathrm{E} 7.117^{\circ} \mathrm{N} 40.000^{\circ} \mathrm{E}$ and an elevation of 2,480 meters $(8,175 \mathrm{ft})$ above sea level with average annual rain fall of $1100 \mathrm{~mm}$. It has a moderately highland climate with average minimum and maximum temperature ranges of $8{ }^{\circ} \mathrm{C}$ and $22^{\circ} \mathrm{C}$, respectively (source Robe meteorology station office). The seven sampling points of the study area were randomly selected from dump sites and farm lands, using GPS (global positioning systems) (Figure 1). Site 1, Maddawalabu University farm land; site 2, dump site were found in Maddawalabu University; site 3, dump site were found around Mebrat Hayle; site 4, Radio station dump site; site 5,farm land were found out of the town; site 6, Robe TVET school farm land; site 6, the farm land found around Shaya river.

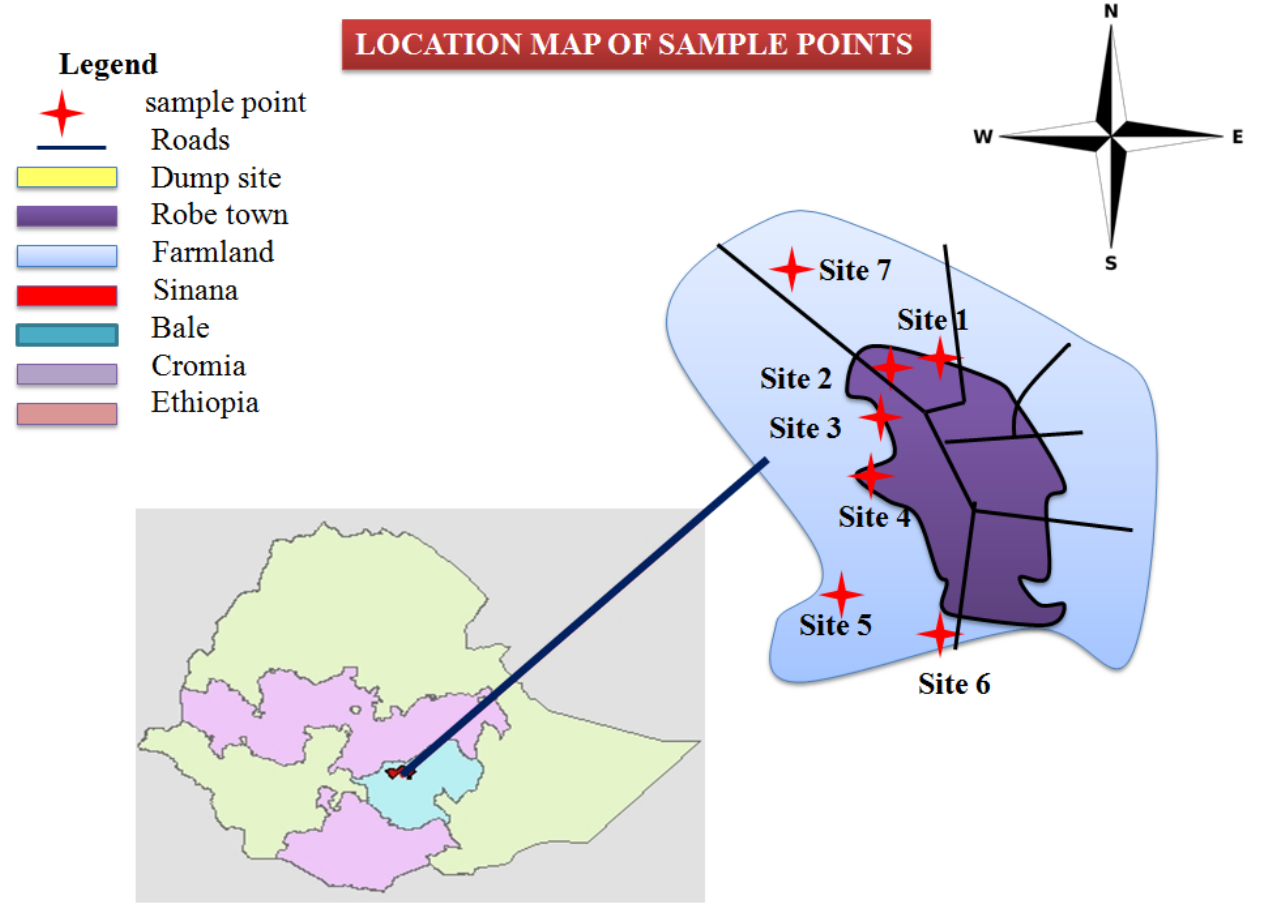

Figure 1. Map of the study area with sampling sites.

\section{Sample Collection}

The composite soil samples were collected from each seven sampling sites using Auger from 0-15 cm borehole after the removal of grassy part. Polyethylene bag was used to collect the soil samples. The soil 
samples were air dried until constant weight were obtained, then grounded with ceramic pestle and mortal and sieved with $2 \mathrm{~mm}$ sieve. The dried soil samples were kept packed with plastic bag till analysis.

\section{Soil physicochemical analysis}

Soil $\mathrm{pH}$ was determined using a digital $\mathrm{pH}$ meter, according to the methodology suggested by Estefan et al. (2013). Sand/Silt/Clay and moisture content of the soil determined by hydrometer method and Gravimetric method, respectively (Wufem et al., 2014). The organic carbon content of the soil samples were determined by loss on ignition method (Maguire and Heckendorn, 2005).

\section{Soil heavy metal analysis}

Heavy metals ( $\mathrm{Fe}, \mathrm{Zn}, \mathrm{Cu}, \mathrm{Pb}, \mathrm{Cr}$ and $\mathrm{Cd}$ ) in soil samples were analyzed using aqua regia digestion method and determined by flame atomic absorption spectrometer at Ezana mining laboratory as described in the manufacturer's instruction manual after the digestion procedure (Ščančar et al., 2000; Adagunodo et al., 2018).

\section{Data analysis}

All the data were captured and entered in to computer and using Microsoft excels statistically using SPSS 16.0. Variation of each parameter between sites was analyzed using one way ANOVA at $95 \%$ confidence level were calculated and the results were presented as mean and standard deviation (Mean \pm SD).

\section{Results and Discussion}

\section{Results of Physicochemical Parameters}

The soil samples collected from in and around Robe town were analyzed for five physicochemical parameters.

\section{Moisture content (MC)}

As described in Table 1, the moisture contents of all sampling area ranged from $14.83 \pm 2.57$ to $19.96 \pm 0.72$ $\%$. Soil collected from dump site (S3) has relatively lower moisture content than the remaining sites but, Soil collected from Robe TVET school farm land (S6) has relatively higher moisture content this may be due to repeated activity of farming. These indicate that the metal ion concentration in Mebrat Hayle dump site might be higher than Around Robe TVET school farm land due to the effect of reducing conditions on the metal ion (Angle et al., 2006). With the exception of S1 the experimental findings of 95\% confidence level showed no significant difference between the farm lands. Comparably there was also no significant difference in all dump sites. Similarly, a study evaluated how different combinations of air temperature and soil moisture content, reflecting realistic climate change scenarios, affect the bioaccumulation kinetics of $\mathrm{Zn}$ and Cd (González-Alcaraz et al., 2018).

Table 1. Mean \pm SD values of the physicochemical parameters of each sampling point $(\mathrm{N}=6)$.

\begin{tabular}{|c|c|c|c|c|c|c|}
\hline \multirow{2}{*}{$\begin{array}{l}\text { Sampling } \\
\text { point }\end{array}$} & \multicolumn{6}{|c|}{ Physicochemical Parameters } \\
\hline & MC \% & $\mathrm{pH}$ & OM\% & Sand $(\%)$ & Silt (\%) & Clay (\%) \\
\hline Site $1^{*}$ & $15.86 \pm 1.93^{b}$ & $6.48 \pm 0.04^{\mathrm{a}}$ & $13.83 \pm 0.49^{a}$ & $53.00 \pm 4.51^{b}$ & $24.84 \pm 4.62^{\mathrm{a}}$ & $22.16 \pm 0.75^{c}$ \\
\hline Site $2^{* *}$ & $17.20 \pm 2.37^{a}$ & $7.60 \pm 0.33^{b}$ & $16.43 \pm 1.87^{\mathrm{a}}$ & $65.33 \pm 2.42^{\mathrm{a}}$ & $23.33 \pm 2.06^{\mathrm{a}}$ & $11.33 \pm 1.03^{\mathrm{a}}$ \\
\hline Site $3^{* *}$ & $14.83 \pm 2.57^{\mathrm{a}}$ & $6.37 \pm 0.34^{\mathrm{a}}$ & $15.93 \pm 0.81^{\mathrm{a}}$ & $61.33 \pm 2.42^{b}$ & $24.33 \pm 1.96^{\mathrm{a}}$ & $14.33 \pm 2.33^{b}$ \\
\hline Site $4^{* *}$ & $17.03 \pm 0.83^{\mathrm{a}}$ & $6.25 \pm 0.25^{\mathrm{a}}$ & $14.05 \pm 0.63^{b}$ & $57.66 \pm 1.96^{c}$ & $25.00 \pm 2.75^{a}$ & $17.33 \pm 1.63^{c}$ \\
\hline Site $5^{*}$ & $18.56 \pm 1.35^{\mathrm{a}}$ & $5.77 \pm 0.08^{b}$ & $16.28 \pm 2.40^{\mathrm{b}}$ & $61.16 \pm 2.56^{\mathrm{a}}$ & $19.33 \pm 1.03^{b}$ & $19.50 \pm 2.50^{\mathrm{b}}$ \\
\hline Site $6^{*}$ & $19.96 \pm 0.72^{\mathrm{a}}$ & $6.01 \pm 0.32^{\mathrm{b}}$ & $14.56 \pm 0.49^{a}$ & $61.33 \pm 2.42^{\mathrm{a}}$ & $24.00 \pm 3.79^{a}$ & $14.33 \pm 1.96^{\mathrm{a}}$ \\
\hline Site $7^{*}$ & $19.66 \pm 3.88^{\mathrm{a}}$ & $6.54 \pm 0.17 \mathrm{a}$ & $16.60 \pm 0.90^{\mathrm{b}}$ & $62.00 \pm 3.57 \mathrm{a}$ & $24.66 \pm 4.50^{\mathrm{a}}$ & $13.33 \pm 3.01^{\mathrm{a}}$ \\
\hline
\end{tabular}

*= Farm land, ${ }^{* *}=$ Dump site, MC : Moisture content, OM : Organic matter

NB: The mean with the same latter in the same star are not significantly different $(\mathrm{P} \leq 0.05)$.

\section{Soil pH}

The $\mathrm{pH}$ values of the soil samples in all the sites ranged from $5.77 \pm 0.08$ to $7.60 \pm 0.33$. This result seems that the soils obtained from all sampling area were slightly acidic except Maddawalabu University dump site which is slightly basic. Since at low pH (acidic) metals are more soluble and more bioavailable in the soil solution, the range of $\mathrm{pH}$ values obtained in all study area except site S2 will favors plant uptake of heavy metal and hence toxicity problems are possible (Osakwe et al., 2015). Horeboka farm land shows slightly acidic from the other farm lands; this may be due to application of fertilizer in the farm lands. Apart this soil acidity cause by the removal of basic elements through leaching and crop uptake (Wufem et al., 2014). At 95\% confidence level S2 has significant difference from the two remaining dump sites this may be only house hold garbage is dumped in the area. and in farm lands S1 and S7 has significance difference from S5 and S6. 


\section{Organic matter (OM) content}

The OM contents of all sampling area were ranged from $13.83 \pm 0.49$ at $\mathrm{S} 1$ to $16.60 \pm 0.90$ at S7. The values obtained from the dump sites did not differ significantly at 95\% confidence level except S4, but significant difference showed S1 and S6 with S5 and S7 in farm lands. Brady and Weil (2008) classified organic matter level of soil into classes: $<0.4 \%$ organic matter of soil as very low, $1.0-1.5 \%$ as moderate organic matter soil and $>2.0 \%$ as high organic matter soil. Based on this, all the soils may consider under high organic matter. The deposition and decomposition of huge quantities of many organic wastes and sewage sludge might be responsible for the organic matter enrichment in this soil. Apart from this accumulation and subsequent decomposition of plant residues also result in building organic matter (Gairola and Soni, 2010; Ai et al., 2018).

\section{Sand/Silt/Clay Content}

As described in table 1 the sand/silt/clay content of the soil ranged from $53.00 \pm 4.51$ (S1) to $65.33 \pm 2.42$ (S2), $19.33 \pm 1.03$ (S5) to $24.84 \pm 4.62$ (S1) and $11.33 \pm 1.03$ (S2) to $19.50 \pm 2.50$ (S5) present of sand, silt and clay respectively, these indicate that the soil contained higher composition of sand followed by silt and clay in all the sampling sites. The statistical analysis showed that there was significant difference in the sand content between the dump sites, but no significant difference showed in farm lads with exception of S1 were $(P \leq 0.05)$. The silt content was also not significantly differ at $95 \%$ confidence level except at S5 among the farm lands and not differ significantly in all dump sites, while in clay content S6 and S7 of farm lands sites has significance difference from S1 and S5 but, all dump sites were significantly different at the 95\% confidence level. Trace metals have preferential accumulation in the clay and silt fraction of soil, the concentrations of heavy metal in soil increase with decrease in the sizes of the soil particles (Inobeme et al., 2014). This sandy nature of the soil might be due to the depletion of humus from the soil.

\section{Heavy metal concentrations in soil samples}

As per results from Table 2, the level of $\mathrm{Cr}$ content in different sampling area was ranged from $32.53 \pm 3.51$ (S5) to $41.81 \pm 1.06 \mathrm{ppm}(\mathrm{S} 2$ ). The result reveals that the concentration of $\mathrm{Cr}$ is higher in dump sites than the farm lands except S4 sampling area. The highest level of $\mathrm{Cr}$ content recorded at S2 dumpsite, that may be due to different contaminants such as disposal of Cr containing wastes and the lowest value of S5 which is Horeboka farm land indicates that the place is less polluted due to less existence of anthropogenic activities because the area is far from the dump site and also from the Town. Statistical analysis at $95 \%$ confidence level also showed that there was no significant variation in the Cr concentrations among dump sites with the exception of S4. There were no significant variations among all farmland except at S7. High concentration of Cr obtained in S7 from the farm lands might be due to more liquid waste reach the area. The concentration of $\mathrm{Cr}$ is in all sites were below the maximum permissible limit (Ewers, 1991).

Table 2. Heavy metal concentrations in soil samples

\begin{tabular}{lcccccc}
\hline \multicolumn{7}{c}{ Metal concentration of soil sample, ppm } \\
\hline Sites & $\mathbf{C r}$ & $\mathbf{C d}$ & $\mathbf{C u}$ & $\mathbf{Z n}$ & $\mathbf{F e}$ & $\mathbf{P b}$ \\
\hline S1 $^{*}$ & $34.90 \pm 1.09^{\mathrm{a}}$ & $0.88 \pm 0.24^{\mathrm{a}}$ & $37.44 \pm 2.72^{\mathrm{b}}$ & $96.41 \pm 1.13^{\mathrm{a}}$ & $44583.22 \pm 3067.42^{\mathrm{a}}$ & $19.10 \pm 0.65^{\mathrm{ab}}$ \\
S2 $^{* *}$ & $41.81 \pm 1.06^{\mathrm{a}}$ & $0.93 \pm 0.24^{\mathrm{a}}$ & $37.06 \pm 2.10^{\mathrm{b}}$ & $170.48 \pm 1.51^{\mathrm{a}}$ & $49012.18 \pm 2692.20^{\mathrm{a}}$ & $19.43 \pm 1.98^{\mathrm{b}}$ \\
S3 $^{* *}$ & $41.47 \pm 1.57^{\mathrm{a}}$ & $0.67 \pm 0.22^{\mathrm{a}}$ & $28.54 \pm 1.00^{\mathrm{a}}$ & $83.67 \pm 1.93^{\mathrm{b}}$ & $36482.75 \pm 1838.83^{\mathrm{b}}$ & $20.77 \pm 0.46 \mathrm{a}$ \\
S4 $^{* *}$ & $34.77 \pm 4.90^{\mathrm{b}}$ & $0.76 \pm 0.22^{\mathrm{a}}$ & $27.69 \pm 0.86^{\mathrm{a}}$ & $74.05 \pm 8.09^{\mathrm{c}}$ & $33483.55 \pm 1470.02^{\mathrm{c}}$ & $20.51 \pm 0.85^{\mathrm{ba}}$ \\
S5 $^{*}$ & $32.53 \pm 3.51^{\mathrm{a}}$ & $0.57 \pm 0.21^{\mathrm{c}}$ & $26.54 \pm 0.68^{\mathrm{a}}$ & $72.79 \pm 3.30^{\mathrm{b}}$ & $33973.75 \pm 1320.36^{\mathrm{b}}$ & $18.04 \pm 0.37^{\mathrm{a}}$ \\
S6 $^{*}$ & $32.91 \pm 1.43^{\mathrm{a}}$ & $0.79 \pm 0.26^{\mathrm{ac}}$ & $27.93 \pm 1.03^{\mathrm{a}}$ & $66.98 \pm 1.09^{\mathrm{c}}$ & $35753.48 \pm 340.31^{\mathrm{b}}$ & $19.64 \pm 0.64^{\mathrm{b}}$ \\
S7 $^{*}$ & $35.49 \pm 0.84^{\mathrm{b}}$ & $0.84 \pm 0.13^{\mathrm{a}}$ & $34.35 \pm 1.59^{\mathrm{c}}$ & $97.01 \pm 2.69^{\mathrm{a}}$ & $45008.2 \pm 1665.74^{\mathrm{a}}$ & $16.08 \pm 0.32^{\mathrm{c}}$ \\
Ewers (1991) & 100 & 3.00 & 100 & 300 & 5000 & 100 \\
\hline
\end{tabular}

**=dump site, ${ }^{*}=$ farm lands

NB: the mean with the same latter in the same star are not significantly different $(\mathrm{P} \leq 0.05)$.

The Cd content was the lowest at S5 while the highest at S2 with the mean values that ranged from $0.57 \pm$ $0.21 \mathrm{ppm}$ to $0.93 \pm 0.24 \mathrm{ppm}$, respectively. The lowest concentration of S5 might be due to no waste disposal in the area. The highest Cd content recorded in site S2 might be due to disposal of impurity in several products, including phosphate fertilizers, detergents. The statistical analysis using one way of ANOVA at 95\% confidence level showed no significant difference in the concentrations of cadmium among in all dump sites, and also with the exception of S5 no significant difference was showed among the farm lands. The concentration of $\mathrm{Cd}$ in all sampling area shows below the maximum permissible limits that recommended by Ewers.

The value of $\mathrm{Cu}$ in soil content is highest at $\mathrm{S} 1$ with mean value of $37.44 \pm 2.72 \mathrm{ppm}$ while the lowest at S5 with mean value of $26.54 \pm 0.68 \mathrm{ppm}$. The one way ANOVA analysis showed that there are not significantly 
differ within the dump sites except S2, and also except S1 with S7 no significance difference showed within the farm lands. The highest value of $\mathrm{Cu}$ in $\mathrm{S} 1$ might be derived from chemical fertilizers and pesticides used in agricultural land. Concentrations $\mathrm{Cu}$ of in all seven sites are below the maximum permissible agricultural soil concentration recommended by Ewers (1991).

The $\mathrm{Zn}$ content was lowest at $\mathrm{S} 6$ the mean value was ranged from $66.98 \pm 1.09 \mathrm{ppm}$ while highest value is observed at S2 the mean value ranged of $170.48 \pm 1.51 \mathrm{ppm}$ at the $95 \%$ confidence level indicated that there was statistically significance difference among all dump sites and also among farm lands except S1 with S7. The higher Zn content in S2 is recorded might be due to repeated activity of waste combustion and dumping of pesticide can. While the lowest value of S6 recorded might be due to less existence of anthropogenic activities. The level of $\mathrm{Zn}$ concentration observed in all sites was below the maximum permissible that recommended by Ewers. The level of Fe content in different sampling sites was ranged from $33483.55 \pm$ $1470.02 \mathrm{ppm}$ of S4 to $49012.18 \pm 2692.20 \mathrm{ppm} \mathrm{S2}$. The one way ANOVA analysis showed that S1 and S7 are significantly different from S5 and S6 in farm lands and also in all dump sites at the 95\% confidence level, this might be because of the same contaminant reach S1 with S7 and S5 with S6 due to the area were not far each other. High concentration of Fe in Maddawalabu dump site might be due to high discharge and burning of cosmetics material, thin and cans. While relatively less in the others. The experimental value of $\mathrm{Fe}$ concentration from all sites was far higher than the maximum permissible agricultural soil concentration recommended by Ewers.

The value of $\mathrm{Pb}$ in sampling area was ranged from $18.04 \pm 0.37 \mathrm{ppm}$ to $20.77 \pm 0.46 \mathrm{ppm}$, the lowest value observed in Horeboka farm land while the highest value observed at Mebrat Hayle dump site. There was no significant difference in concentration of Pb across the farm lands except S7 and also dump sites except S3 with S4 at 95\% confidence level. The lowest value of S5 might be due to less existence of anthropogenic activities in area, while the highest value of S3 might be due to disposal of more wastes from garages and combustion of fossil fuels. The levels of $\mathrm{Pb}$ obtained in the soil from all site below the maximum permissible limit of agricultural soil concentration that reported by Ewers (1991). The obtained results showed that the metal concentration decreased in the order of $\mathrm{Fe}>\mathrm{Zn}>\mathrm{Cr}>\mathrm{Cu}>\mathrm{Pb}>\mathrm{Cd}$, in both dump sites and farm lands. From the analyzed metals, the concentration of most metal were higher in dump site than the farm lands except radio station dump site, lower concentration of this site might be due to less and only domestic waste were dumped in the area. Generally, in dump sites disposal of high metal wastes, sewage sludge and waste combustion might be responsible for high concentration of metal.

\section{Conclusion}

The present study showed that the results obtained from the physicochemical analysis of all soil samples were slightly acidic except S2 which is slightly alkaline and contained high amounts of organic matters and sandy nature of soil followed by silt and clay content. The results of heavy metals indicated that, they are in lower concentrations in all sites than of the maximum permissible limit reported by Ewers with the exception of Fe. Finally, based on the results, we concluded that the obtained level of metals concentrations was low in all sites and safe for agricultural activities. But, researchers reported there is an indication that heavy metals are not biodegradable, while they are accumulated in the environment (Mtuazi et al., 2015); it may detoriate the soil quality. Therefore we recommended that Different measures must be taken to minimize soil pollution; the farmers should be educated on the problems associated with excessive usage of fertilizers and other chemicals. New modern sanitary landfill need to be developed thus the open dumping of waste should be discouraged and proper drainage should maintain for liquid wastes. Periodic monitoring of soil environment for heavy metals in the study area is recommended and in future, further study should be done to investigate the levels of different heavy metals, common cations, sediment concentrations, and other soil physicochemical parameters of the soils in the study area.

\section{Acknowledgement}

The authors would like to acknowledge Maddawalabu University for financial support and the use of the laboratory. The authors also thankful to the Ezana Mining PLC Laboratory, Mekele for facilitating laboratory accesses for this study.

\section{References}

Adagunodo, T.A., Sunmonu, L.A., Emetere, M.E., 2018. Heavy metals' data in soils for agricultural activities. Data in Brief 18: 1847-1855.

Addis, W., Abebaw, A., 2014. Analysis of selected physicochemical parameters of soils used for cultivation of garlic (Allium sativum L.). Science, Technology and Arts Research Journal 3(4): 29-35. 
Ai, S., Liu, B., Yang, Y., Ding, J., Yang, W., Bai X., Naeem, S., Zhang, Y, 2018. Temporal variations and spatial distributions of heavy metals in a wastewater-irrigated soil-eggplant system and associated influencing factor. Ecotoxicology and Environmental Safety 153: 204-214.

Ali, S.M., Pervais, A., Afzal, B., Hamid, N., Yasmin, A., 2014. Open dumping of municipal solid waste and its hazardous effect on soil and vegetation diversity at waste dumping site of Islamabad city. Journal of King Saud University Science 26(1): 59-65.

Angle, S.J., Baker, A.J.M., Whiting, S.N., Chaney, R.L., 2003. Soil moisture effects on uptake of metals by Thlaspi, Alyssum, and Berkheya. Plant and Soil 256(2): 325-332.

Aydinalp, C., Cresser, M.S., 2009. Distribution of heavy metals in irrigated vertisol profiles in semiarid region of Turkey. Polish Journal of Environmental Studies 18(4): 539-545.

Brady, N.C., Weil, R.R.,2008. The nature and properties of soils. Fourteenth Edition, Prentice Hall, New York. USA. 965p.

Dawaki, U.M., Dikko, A.U., Noma, S.S., Aliyu, U., 2013. Heavy metals and physicochemical properties of soils in Kano urban agricultural lands. Nigerian Journal of Basic and Applied Science 21(3): 239-246.

Estefan, G., Sommer, R., Ryan, J., 2013. Methods of Soil, Plant,and Water Analysis: A manual for the West Asia and North Africa region. International Center for Agricultural Research in the Dry Areas (ICARDA). Third Edition. Beirut, Lebanon.

Ewers, U., 1991. Standards, guidelines and legislative regulations concerning metals and their compounds. In: Metal and their compounds in the environment: Occurrence, Analysis and Biological Relevance. Maria, E. (Ed.), VCH, Weinheim, New York, USA. pp. 458-468.

Gairola, S.U., Soni, P., 2010. Role of soil physical properties in ecological succession of restored mine land - A case study. International Journal of Environmental Sciences 1(4): 475-480.

González-Alcaraz, M.N., Loureiro, S., van Gestel, C.A.M., 2018. Toxicokinetics of Zn and Cd in the earthworm Eisenia andrei exposed to metal-contaminated soils under different combinations of air temperature and soil moisture content. Chemosphere 97: 26-32.

Hong, A.H., Law, P.L., Selaman, O.S., 2014. Heavy metal concentration levels in soil at lake Geriyo irrigation site, Yola, Adamawa State, North Eastern Nigeria. International Journal of Environmental Monitoring and Analysis 2(2): 106111.

Inobeme, A., Ajai, A.I., Iyaka, Y.A, Ndamitso, M., Uwem, B., 2014. Determination of physicochemical and heavy metal content of soil around paint industries in Kaduna. International Journal of Scientific \& Technology Research 3(8): 221-225.

Maguire, R.O., Heckendorn, S.E., 2005. Laboratory procedures. Virginia Tech Soil Testing Laboratory. Virginia Cooperative Extension, Publication 452-881. Available at [25.11.2017]: https://vtechworks.lib.vt.edu/bitstream/handle/10919/55039/452-881.pdf?sequence=1\&isAllowed=y

Mtunzi, F.M., Dikio, E.D., Moja, S.J., 2015. Evaluation of heavy metal Pollution on soil in Vaderbijlpark, South Africa. International Journal of Environmental Monitoring and Analysis 3(2): 44-49.

Olayinka, K.O., Oyeyiola, A.O., Odujebe, F.O., Oboh, B., 2011. Uptake of potentially toxic metal by vegetable plants grown on contaminated soil their potential bioavailability using sequential extraction. Journal of Soil Science and Environmental Management 2(8): 220-227.

Osakwe, S.A., Okolie, L.P., 2015. Physicochemical characteristics and heavy metals contents in soils and cassava plants from farmlands along a major highway in Delta State, Nigeria. Journal of Applied Sciences and Environmental Management 19(4): 695-704.

Parameswari, K., Padmini, T.K., Mudgal, B.V., 2015. Assessment of soil contamination around municipal solid waste dumpsite. Indian Journal of Science and Technology 8 (36).

Rahaman, M.S., Nessa, F., Hoque, M.M., Rehnuma, M., Islam, M.S., 2015. Physicochemical properties and heavy metal concentration in soil of industrial area, Zirani, Savar, Dhaka. Journal of Environmental Science and Natural Resources 8(1): 65-68.

Ščančar, J., Milačič, R., Stražar, M., Burica, O., 2000. Total metal concentrations and partitioning of Cd, Cr, Cu, Fe, Ni a nd Zn in sewage sludge. The Science of the Total Environment 250 (1-3): 9-19.

Sumithra, S., Ankalaiah, C., Janardhana, R.D., Yamuna, R.T., 2013. A case study on physicochemical characteristics of soil around industrial and agricultural area of Yerraguntla, Kadapa district, A.P, India. International Journal of Geology, Earth \& Environmental Sciences 3(2): 28-34.

Wufem, B.M., Ibrahim, A.Q., Maina, H.M., Gungsat, N.J., Barnabas, N.J., 2014. Quality evaluation and physico-chemical properties of soils around a cement factory in Gombe State, Nigeria. International Conference on Advances in Agricultural, Biological \& Environmental Sciences (AABES-2014) Oct 15-16, 2014 Dubai, UAE. 